\title{
Structure and Dominance of Species in Mangrove Forest on Kutai National Park, East Kalimantan, Indonesia
}

\author{
Muli Edwin ${ }^{1 *}$, Iin Sumbada Sulistyorini ${ }^{1}$, Erny Poedjirahajoe $^{2}$, Lies Rahayu Wijayanti Faida ${ }^{2}$, \\ Ris Hadi Purwanto ${ }^{3}$, Imanuddin ${ }^{4}$
}

\author{
${ }^{1}$ Forestry of Study Program, High School of Agriculture (STIPER East Kutai), \\ Jl. Sukarno-Hatta No. 1, North Sanggatta, Indonesia 75611 \\ ${ }^{2}$ Department of Forest Resources Conservation, Faculty of Forestry, Gadjah Mada University, \\ Jl. Agro No. 1. Bulaksumur, Sleman Yogyakarta, Indonesia 55281 \\ ${ }^{3}$ Department of Forest Management, Faculty of Forestry, Gadjah Mada University, \\ Jl. Agro No. 1. Bulaksumur, Sleman Yogyakarta, Indonesia 55281 \\ ${ }^{4}$ Marine Science Study Program, High School of Agriculture (STIPER East Kutai), \\ Jl. Sukarno-Hatta No. 1, North Sanggatta, Indonesia 75611
}

Received August 3, 2020/Accepted March 17, 2021

\begin{abstract}
The Kutai National Park (KNP) is located in East Kutai Regency on East Kalimantan Province. It is endowed with numerous pristine of mangrove forest. However, the information to the species composition and diversity of KNP mangrove was still scanty. Twenty-one of mangrove species were recorded using the quadratic transects survey method (total plot area of $1.7 \mathrm{ha}$ ). Main species of mangrove communities was Avicennia lanata, A. marina, Bruguiera gymnorrhysa, B. sexangular, Ceriops tagal, Rhizophora apiculata, R. mucronata, and Sonneratia alba. Mangrove density was recorded reached as 1,699 trees ha ${ }^{-1}$, saplings of 4,395 $\mathrm{ha}^{-1}$, and seedlings of 25,348 ha- . Significant tree density was founded in Pandan Bay Estuary. While in the Lombok Bay and the Kaba Bay were significant for sapling and seedling categories. Importance value index of mangrove species in the three study locations for three growth categories (tree, sapling, and seedling) showed significant differences (p-value $>0.05$ ). Mangrove stand at three study locations had almost the same characteristics. The species diversity and evenness index has shown the same distribution pattern. This study's findings suggest that KNP mangrove forest stand was not heavily damaged even though there were many human activities. This mangrove could be managed and conserved for multi-sectoral purposes such as ecotourism, research, biodiversity, and education rather than solely as a nature conservation area.
\end{abstract}

Keywords: forest composition, diversity, mangrove, conservation

*Correspondence author, email: edwin.kutim@gmail.com, tel./fax.+62-549-2031637

\section{Introduction}

Indonesia is an archipelago, and there are more than 17,504 islands with a coastline of approximately $95,181 \mathrm{~km}$, which are several meters or even kilometres filled with mangrove forests. In 2007, Indonesian mangroves' area was estimated at around 7,758,411 ha with $30.7 \%$ good condition, $27.4 \%$ lightly damaged, and $41.9 \%$ heavily damaged (Kusmana, 2014). Southeast Asia has the largest proportion $(33.8 \%)$ of global mangrove forests (Thomas et al., 2017). The largest mangrove in Southeast Asia is in Indonesia, which is around $60 \%$. Mangroves are scattered in several islands, the largest in Papua around 55\%, in Sumatera around $19 \%$, and in Kalimantan around 16\% (Giesen et al., 2007). The area of mangroves in East Kalimantan is around 367,000 ha (Noor et al., 1999).

Mangroves in Southeast Asia provide valuable ecosystem services for human well-being (Brander et al.,
2012). Mangroves support various wildlife, fishery resources and provide various commercial products and ecological services (Saenger, 1999). The existence of mangrove ecosystems is important for the environment and other organisms because of their ecological and economic values (Herison et al., 2014). Mangrove forests are one of the most productive ecosystems in the world. The existence of mangroves enriches coastal water, produces commercial forest products, protects coastlines, and supports coastal fisheries (Kathiresan \& Bingham, 2001). In Indonesia, there are various species of mangroves consisting of about 157 species ( 52 species of tree, 21 species of shrub, 13 species of liana, seven species of palm, 14 species of grass, eight species of herb, three species of parasite, 36 species of epiphyte, three species of fern) (Kusmana \& Sukristijiono, 2016).

In Balikpapan Bay on East Kalimantan, there were 13 
species recorded with different distribution and density patterns. The species that dominated based on the importance value index (IVI) was Rhizophora apiculata (Warsidi \& Endayani, 2017). In Bulungan North Kalimantan there were 11 species. The species found are dominated by $R$. mucronata and $R$. apiculata from the family of Rhizophoraceae (Kartika et al., 2018). In Sebatik Nunukan Island North Kalimantan, there are 16 reported species and dominated by Sonneratia alba (Ardiansyah et al., 2012). The mangrove formation in the Mahakam Delta of Kutai Kertanegara East Kalimantan, species were found, namely Avicennia officinalis, A. alba, $A$. lanata, A. marina, S. caseolaris, S. alba, S. ovata, R. apiculata, R. Mucronata, Acrostichum aureum, Heriteira littoralis, Tigillarium oncosperm, Nypa fruticans (Fawzi \& Husna, 2017). Then based on a 2013 research report in the Kutai National Park (KNP) mangrove communities found were as many as 12 species consisting of $R$. mucronata, $R$. apiculata, $R$. stylosa, Bruguiera sexangula, Ceriops decandera, C. tagal, S. alba, S. caseolaris, A. alba, Xylocarpus granatum, N. fruticans, and Pandanus tectorius (Budiarsa \& Rizal, 2013). Along with current development, regional development, population distribution and changes in land use, then the mangroves need to be evaluated periodically. Previous research on mangrove vegetation in KNP was mostly carried out in Lombok Bay, while a wide distribution of mangroves is also found in the Kaba Bay and Pandan Bay Estuary. This study was done to strengthen the information as primary data related to mangrove forest diversity and sustainability.

Anthropogenic disruption to the extent of mangrove forests that occur in Southeast Asia is relatively extensive. The disturbance was due to aquaculture/agricultural practices during the 1996-2010 period (Thomas et al., 2017). KNP mangrove forests continue to experience pressure due to increasing human activities for settlement, agriculture, and other activities (Sayektiningsih \& Gunawan, 2012). Based on the spatial analysis in 2011, the total area of open mangrove forests is $\pm 23,0 \%$ (Wijaya, 2011) then 2013 the mangrove forest that has been opened is $\pm 26.2 \%$, namely for ponds and open land. KNP is recognized as one of the National Parks in Indonesia designed to preserve Borneo's tropical forest ecosystem, including mangrove ecosystem that has high productivity (Budiarsa \& Rizal, 2013). Based on these conditions and literature reviewed, it is important to do an inventory and evaluation of mangroves structure and composition. The mangrove forest in KNP is a nature conservation area (kawasan pelestarian alam, KPA) which must be preserved. This study's main objective was to determine the composition, dominance, and diversity of mangroves to strengthen knowledge about biodiversity and the preservation of mangrove forests as a natural conservation area. The second objective was to increase the renewal of mangrove vegetation data for future mangrove management.

\section{Methods}

Study area KNP is the oldest conservation area in Indonesia. The Dutch East Indies government established the area in 1932 under Wildreservaat Koetai, then became Forestry Reserve in 1934 (KNP, 2005). KNP mangroves are primary natural forests. Some mangrove forests have experienced disturbance, especially in the Lombok Bay (LB), for mangroves in Kaba Bay (KB), and Pandan Bay Estuary (PBE), the disturbance to the forest is still relatively small. This research was conducted in mangrove forests in three locations, namely $\mathrm{LB}, \mathrm{KB}$, and $\mathrm{PBE}$ on Kutai KNP. Administratively, the area is included in the East Kutai Regency, East Kalimantan Province, Indonesia. The estimated area of mangrove forest observed in LB is 1,442.2 ha, $\mathrm{KB}$ is $1,120.8 \mathrm{ha}$, and PBE is 835.4 ha. The research location as presented in Figure 1 is geographically located between latitude $\mathrm{N} 0^{\circ} 26^{\prime} 24.737^{\prime \prime}-\mathrm{N} 0^{\circ} 11^{\prime} 13.153^{\prime \prime}$ and longitude E117³3'35.873"-E117²9'58.92". This research

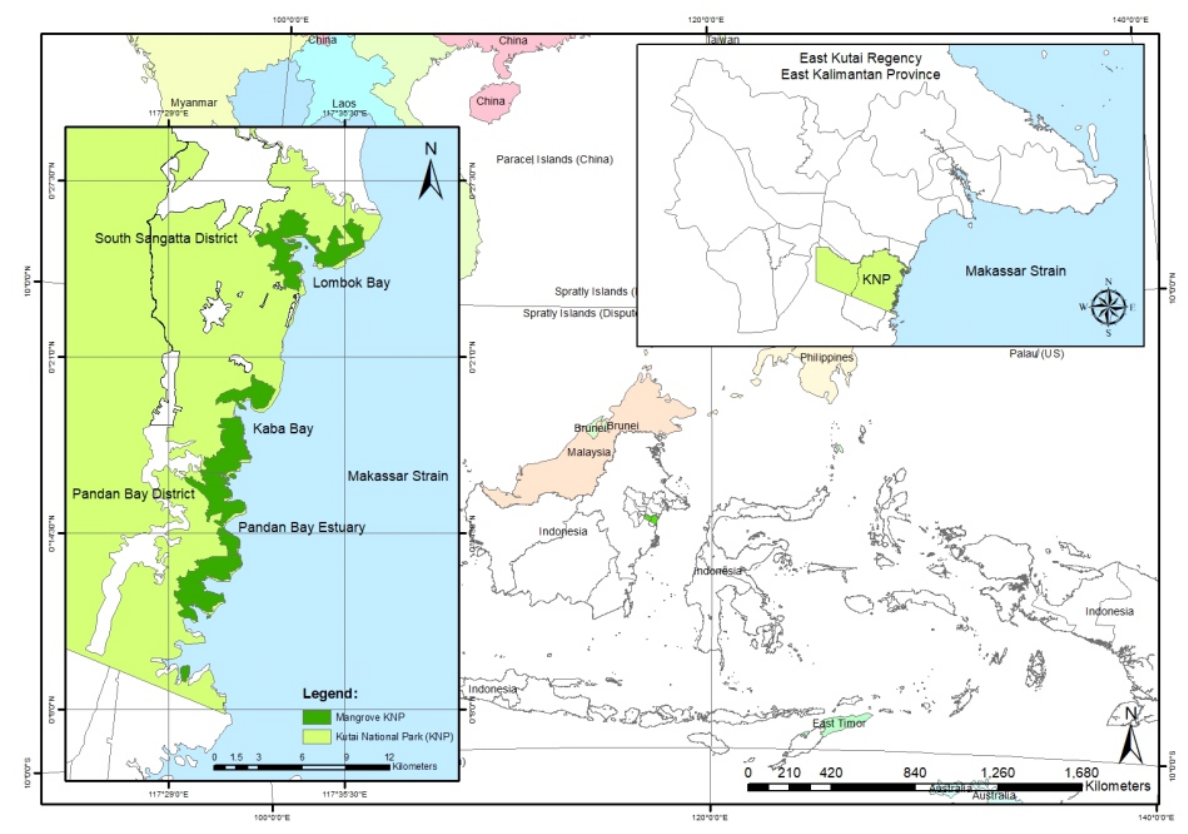

Figure 1 Location of the mangrove forest in Kutai National Park, East Kalimantan. 
was conducted for approximately four months, namely from January to April 2019. The research stages consisted of research preparation, literature review, field survey, data processing, and report of research result.

Materials and research tools The material used in this study consisted of mangrove vegetation. The tools used consist of a Global Positioning System (GPS) to determine the survey location, Arc-GIS Software (Arc-view) for making study maps. Phi-band to measure tree diameter, clinometer to measure tree height, roll meters and ropes to measure or make research plots, mangrove guidebook for mangrove identification, measuring tape for marking plots, and cameras for research documentation.

Data collection and sampling techniques The research method used is quantitative descriptive method. The research plot was made by purposive sampling with multiple plots (quadratic transects) following the standards described by (English et al., 1997). At the three study sites, each consisted of 6 stations. The number and size of plot areas in each location are proportionally considered according to the area of mangrove forest. The total number of plots was 170 plots with a 1.7 ha (sampling intensity $0.05 \%$ ). The research plot size is $10 \times 10 \mathrm{~m}$ for trees (diameter $\geq 10 \mathrm{~cm}$ ), $5 \times 5 \mathrm{~m}$ for stakes (height above $1.5 \mathrm{~m}$ and diameter $\leq 10 \mathrm{~cm}$ ), and $2 \times 2$ $\mathrm{m}$ for seedlings/saplings (height below $1,5 \mathrm{~m}$ ). Placement of the plot is carried out extending from the seashore or coastline (Figure 2).

Data analysis Vegetation data were analyzed using the IVI of species. IVI is obtained based on density, relative density, frequency, relative frequency, dominance, relative dominance. IVI for trees is calculated based on the sum of relative density, relative frequency, and relative dominance. IVI for seedling and sapling is calculated based on the sum of relative density and relative frequency (Curtis \& Mcintosh, 1950). The highest IVI determines the dominant species at each of the growth stages.

The vegetation data is also used for community index analysis, such as the Shannon-Weiner diversity index $\left(\mathrm{H}^{\prime}\right) . \mathrm{H}$ 'values can be categorized as very high if $\mathrm{H}^{\prime} \geq 4$, high if $\mathrm{H}^{\prime} \geq$ 34 , medium if $\mathrm{H}^{\prime} \geq 23$, low if $\mathrm{H}^{\prime} \geq 12$, and very low $\mathrm{H}^{\prime} \leq 1$ (Barbour et al., 1987; Djufri et al., 2016; Eddy et al., 2019).
Furthermore, the evenness index of species Pielou (J) is calculated, showing the level of individual distribution of each species. J value (Pielou, 1975) Magnitude $\mathrm{J}<0.3$ indicates low species evenness, $0.3<\mathrm{J}<0.6$ indicates moderate species evenness and $\mathbf{J}>0.6$ indicates relatively high species evenness (Magurran, 1988; Ghufrona et al., 2015).

Comparisons between the three study sites and the three growth categories (tree, sapling and seedling) are known by conducting a t-test. The difference in mangrove characteristics between the three locations in each parameter uses a $95 \%$ confidence level. The significant difference is determined if $p$-value $>0.05$ then Ho is rejected and Ha is accepted, or the value of the resulting parameter is greater than the mean value used for the significant test.

\section{Results and Discussion}

Species composition Total mangroves recorded at the study site were 21 species, 20 species were true mangroves and one mangrove association species. There is only one species of mangrove association. There is a possibility that other species of mangrove association cannot adapt to the KNP mangrove ecosystem. These 21 species consist of 9 families and mangrove species often founded from the family Rhizopharaceae, Combretaceae and Avicenniaceae (Table 1). In two locations (KB and PBE) each has 15 species. Besides having the same regional characteristics, both of these locations are also mangrove forests in one stretch with a coastline of about $17.02 \mathrm{~km}$. Both of these locations were of two species not found, namely Lumnitzera racemose and Acrosticum speciosum. Both species were only found in LB mangrove. The total of mangrove species in LB were 14 species and species not found in these locations such as $N$. fruticans, $A$. alba, $C$. decandera, $P$. tectorius, $B$. cylindrical, and Scyphiphora hydrophyllacea. The species not found were found in two research locations (KB and PBE).

KNP has broad mangrove potential $\pm 5,192.5$ ha. Based on a 2014 research report, the mangrove community consisted of 12 species from 6 families. These species was $R$. mucronata, $R$. apiculata, $R$. stilosa, B. sexangula, $C$. decandera, C. tagal, S. alba, S. caseolaris, A. alba, X. granatum, N. fruticans, P. tectorius (Budiarsa \& Rizal,

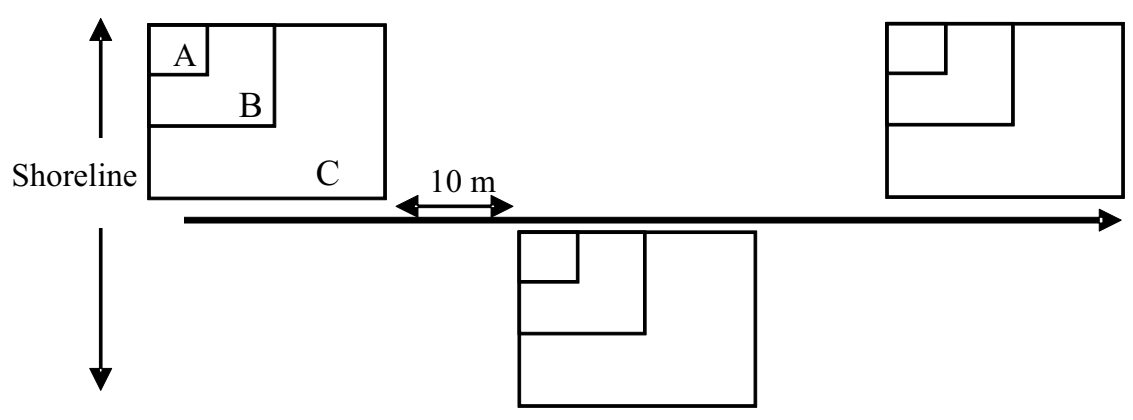

Figure 2 Scheme of sample plots placement for observing mangroves. A = seedling observation plot $\left(2 \times 2 \mathrm{~m}^{2}\right)$; $\mathrm{B}=\operatorname{sapling}$ observation plot $\left(5 \times 5 \mathrm{~m}^{2}\right) ; C=$ tree observation plot $\left(10 \times 10 \mathrm{~m}^{2}\right)$ 
Table 1 List of plant species recorded in the Kutai National Park mangrove forest

\begin{tabular}{|c|c|c|c|c|c|c|}
\hline \multirow{2}{*}{ Family } & \multirow{2}{*}{ Scientific name } & & \multirow{2}{*}{ Local name } & \multicolumn{3}{|c|}{ Site } \\
\hline & & & & LB & KB & $\mathrm{PBE}$ \\
\hline \multirow[t]{2}{*}{ Arecaceae } & Nypa fruticans Wurmb. & $(\mathrm{TM})$ & Nipah & - & $\sqrt{ }$ & $\sqrt{ }$ \\
\hline & Avicennia alba Blume. & $(\mathrm{TM})$ & Api-api putih & - & $\sqrt{ }$ & - \\
\hline \multirow[t]{3}{*}{ Avicenniaceae } & Avicennia lanata (Ridley). & $(\mathrm{TM})$ & Api-api & $\sqrt{ }$ & $\sqrt{ }$ & $\sqrt{ }$ \\
\hline & Avicennia marina (Forssk.) Vierh. & $(\mathrm{TM})$ & Api-api hitam & $\sqrt{ }$ & - & - \\
\hline & Ceriops decandera Griff. Ding Hou. & $(\mathrm{TM})$ & Kayu merah & - & $\sqrt{ }$ & - \\
\hline \multirow{3}{*}{ Combretaceae } & Ceriops tagal (Perr.) C.B.Rob. & $(\mathrm{TM})$ & Tingi/tengirih & $\sqrt{ }$ & $\sqrt{ }$ & $\sqrt{ }$ \\
\hline & Lumnitzera littorea (Jack) Voigt. & $(\mathrm{TM})$ & Terumtum & $\sqrt{ }$ & $\sqrt{ }$ & - \\
\hline & Lumnitzera racemosa Willd. & $(\mathrm{TM})$ & Dulu' & $\sqrt{ }$ & - & - \\
\hline Meliaceae & Xylocarpus granatum Koening. & $(\mathrm{TM})$ & Nyirih/mirih & $\sqrt{ }$ & - & $\sqrt{ }$ \\
\hline Pandanaceae & Pandanus tectorius Parkinson ex. Z.* & (MA) & Pandan laut & - & $\sqrt{ }$ & $\sqrt{ }$ \\
\hline \multirow{2}{*}{ Pteridaceae } & Acrostichum aureum Linn* & $(\mathrm{TM})$ & Paku laut & - & $\sqrt{ }$ & $\sqrt{ }$ \\
\hline & Acrosticum speciosum Willd.* & $(\mathrm{TM})$ & Paku laut & $\sqrt{ }$ & - & - \\
\hline \multirow{6}{*}{ Rhizopharaceae } & Bruguiera cylindrical (L.) Bl. & $(\mathrm{TM})$ & Tancang putih & - & $\sqrt{ }$ & $\sqrt{ }$ \\
\hline & Bruguiera gymnorrhysa (L.) Lamk. & $(\mathrm{TM})$ & Tancang & $\sqrt{ }$ & $\sqrt{ }$ & $\sqrt{ }$ \\
\hline & Bruguiera sexangula (Lour.) Poir. & $(\mathrm{TM})$ & Tancang & $\sqrt{ }$ & $\sqrt{ }$ & $\sqrt{ }$ \\
\hline & Rhizophora apiculata Blume & $(\mathrm{TM})$ & Bakau akik & $\sqrt{ }$ & $\sqrt{ }$ & $\sqrt{ }$ \\
\hline & Rhizophora mucronata Lamk. & $(\mathrm{TM})$ & Bakau & $\sqrt{ }$ & $\sqrt{ }$ & $\sqrt{ }$ \\
\hline & Rhyzophora stylosa Griff. & $(\mathrm{TM})$ & Bakau & $\sqrt{ }$ & - & $\sqrt{ }$ \\
\hline Rubiaceae & Scyphiphora hydrophyllacea C.F. Gaertn.* & $(\mathrm{TM})$ & Duduk rambat/rayap & - & - & $\sqrt{ }$ \\
\hline \multirow{2}{*}{ Sonneratiaceae } & Sonneratia Alba J.E. Smith. & $(\mathrm{TM})$ & Perepat/pedada & $\sqrt{ }$ & $\sqrt{ }$ & $\sqrt{ }$ \\
\hline & Sonneratia caseolaris (L.) Engl. & $(\mathrm{TM})$ & Berembang & $\sqrt{ }$ & $\sqrt{ }$ & $\sqrt{ }$ \\
\hline
\end{tabular}

Note: *These species were not analyzed for density, basal area, height, or IVI; TM = True mangrove; MA = Mangrove associates; $\sqrt{ }=$ found, $-=$ not found

2013). In Muara Badak mangrove, which is south of the study site and still one coastline is found species, namely $A$. alba, $R$. apiculata, S. alba, B. cylindrica, C. tagal, and N. fruticans (Imanuddin \& Simarangkir, 2012). The northern part of East Kalimantan explained that mangroves in Sebatik Island, Nunukan Regency, North Kalimantan were found in 19 species from 14 families (Ardiansyah et al., 2012). Mangrove communities in Bulungan were found to be of 10 species (Kartika et al., 2018). Of all the species that have been found in previous studies and research in other areas in East Kalimantan, the same species was also found in this study. The similarity in communities occurs due to the similarity of land characteristics in terms of geographical area, climate, water and soil quality conditions. Community differences were in the number of species, distribution, growth stages and density of mangrove vegetation.

Density and importance value index of species Based on the three research locations, it was found that mangrove trees had a density of around 1,699 trees ha ${ }^{-1}$, stakes of 4,395 ha ${ }^{-1}$ and seedlings of 25,348 $\mathrm{ha}^{-1}$. In PBE, the tree and sapling densities were greater, but the seedling density was smaller than the other two locations (Figure 3). Each species has a different number of attendance and density at each research station. One tree has an average of about 93 stems ha $^{-1}, 360$ stems ha ${ }^{-1}$, and 2,563 stems ha ${ }^{-1}$. The three mean values are used for significant tests, with a 95\% confidence level.

The total density of mangrove species in the three study sites in the tree, sapling and seedling categories showed significant differences ( $p$-value $>0.05$ ). The results of t-tests have shown that there are many species of mangroves in three locations above the average value (trees $93 \mathrm{ha}^{-1}$, saplings $360 \mathrm{ha}^{-1}$, and seedlings 2,563 ha- $\mathrm{ha}^{-1}$. The species whose density was below the average value, for the trees' level, there were species of L. racemosa, C. decandera, and $R$. stylosa. The saplings species consisted of $A$. alba, $B$. cylindrical, $C$. decandera, L. racemosa, and $R$. stylosa. For the seedling categories, there was species of $A$. alba, $B$. cylindrica, C. decandera, L. littorea, L. racemosa, $R$. stylosa, and $X$. granatum.

The highest total tree category density was found in PBE $\left(1,052.38 \pm 35.89\right.$ trees $\left.^{-1} \mathrm{a}^{-1}\right)$ which was higher than the other two locations (LB of $938.89 \pm 45.78$ trees $\mathrm{ha}^{-1}$ and $\mathrm{KB}$ of $988.89 \pm 42.65$ trees $\left.\mathrm{ha}^{-1}\right)$. The total density of sapling categories in LB $\left(4,027.78 \pm 99.41 \mathrm{ha}^{-1}\right)$ is higher than the other two locations (KB of 3,874.07 $\pm 106.06 \mathrm{ha}^{-1}$ and PBE of $\left.3,657.14 \pm 124.32 \mathrm{ha}^{-1}\right)$. The total seedling density in LB $\left(4,027.78 \pm 99.41 \mathrm{ha}^{-1}\right)$ was higher than the other two locations (KB of 3,874.07 $\pm 106.06 \mathrm{ha}^{-1}$ and PBE of 3,657.14 $\left.\pm 124.32 \mathrm{ha}^{-1}\right)$. The highest total seedling density in LB $\left(26,041.67 \pm 1,017.78 \mathrm{ha}^{-1}\right)$ and KB $(26,064.81 \pm$ 402.01 ha $\left.\mathrm{ha}^{-1}\right)$, while in $\operatorname{PBE}\left(21,904.76 \pm 602.34 \mathrm{ha}^{-1}\right)$ was 


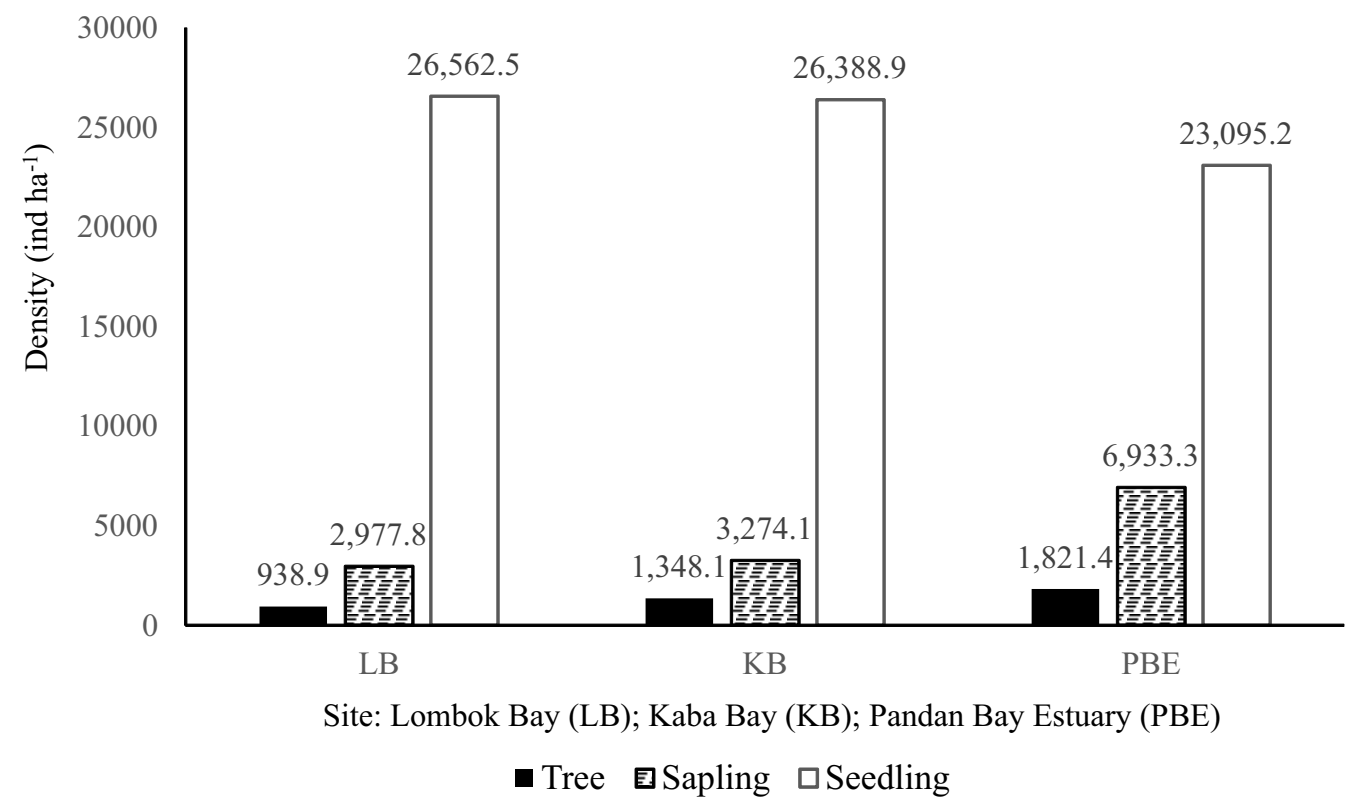

Figure 3 The comparisons of density (ind ha ${ }^{-1}$ ) in three location mangrove forest KNP.

slightly lower. The characteristics of mangrove forests in PBE have a large tree category density with a small number of trees. Whereas in LB and KB have a smaller tree density, the number of individual trees is higher. Mangroves found in PBE have many large tree diameters. The area is also far from various human activities, so it is far from the possibility of forest encroachment. While mangroves' location in LB and $\mathrm{KB}$ is close to settlements, access to mangrove forests is closer, and many human activities can threaten mangrove forests' sustainability.

Overall mangrove in KNP (Table 2) had been recorded $R$. mucronata species have the highest density for all categories, namely trees $\left(644.44 \pm 38.60\right.$ trees $\left.^{-1} \mathrm{a}^{-1}\right)$, saplings $(2140.74 \pm$ $\left.184.83 \mathrm{ha}^{-1}\right)$, and seedlings $\left(14398.15 \pm 1662.68 \mathrm{ha}^{-1}\right)$. Of the 16 species analyzed in KNP mangrove, several species had high density, respectively in the tree category consisting of $R$. mucronata, $R$ apiculata, Bruguiera sexangula, Sonneratia $A l b a$, and B. gymnorrhysa. Sapling category was found in the species of $R$. mucronata, $R$. apiculata, $C$. tagal, $B$. sexangular, and $S$. alba. The seedling category was found in the species of R. mucronata, R. apiculata, S. alba, C. tagal, B. gymnorrhysa, and B. sexangular.

Based on the distribution of IVI of mangrove species in $\mathrm{KNP}$, it was known that the average IVI for trees is $25.4 \%$, saplings is $17.4 \%$, and seedlings is $17.3 \%$. The three IVI mean values are used for the significant test (t-test) with a $95 \%$ confidence level. Total IVI of mangrove species in three locations on three categories of three growth stages (tree, sapling and seedling) showed significant differences ( $p$ value $>0.05)$. The test results prove that not all mangrove types in KNP have IVI below the average value. From 16 species, there were several species of mangroves that have IVI above average. In three locations for all growth stages, eight species have IVI above the average value, namely $A$. lanata, A. marina, B. gymnorrhysa, B sexangular, C. tagal, $R$. apiculata, $R$. mucronata, and $S$. alba. The highest IVI tree category belongs to the species of $R$. mucronata (50.86 \pm $1.31 \%)$ and $B$. sexangula $(45.85 \pm 2.39 \%)$, sapling species of R. mucronata $(33.06 \pm 2.30 \%)$ and $R$. apiculata $(33.01 \pm$ $2.67 \%$ ), the seedling category of $R$. mucronata (33.94 \pm $3.08 \%)$ and $R$. apiculata $(30.12 \pm 0.99 \%)$ (Table 3$)$. Species with low IVI were mangrove species with a $p$-value $>0.05$ or the average IVI was lower than the average used to test. These species were A. alba, B. cylindrica, C. decandera, $L$. littorea, L. racemosa, R. stylosa, S. caseolaris, and $X$. granatum.

In Welu Estuary, Khlung District, Chanthaburi Province, Thailand, $R$. apiculata was recorded with the highest IVI (Suk-ueng et al., 2013). For mangroves in Borneo's coastal, in Sarawak Malaysia, the highest IVI of species was $R$. apiculata (Shah et al., 2016). Mangroves in West Kalimantan's coastal was recorded of $R$. apiculata, $B$. gymnorrhysa, and $B$. sexangular with the highest IVI (Nugroho et al., 2019). In Sebuku, South Kalimantan, for mangroves with the highest IVI, there are species of $R$. mucronata, $R$. apiculata, and S. alba (Ghufrona et al., 2015). In Nunukan and Bulungan North Kalimantan, there were $S$. alba, and $R$. mucronata (Kartika et al., 2018). Mangrove species on the Bontang coastal adjacent to KNP mangroves are dominated by Avicennia sp. and Rhizophora sp. (Nurhidayah \& Gunawan, 2009). The species that have been recorded and dominate were also found in study sites, especially $R$. apiculata. The highest IVI for $R$. apiculata in KNP came second after $R$. mucronata for sapling and seedling categories, then came in third for tree category.

Mangrove forests provide important services throughout the world for human populations and their ecosystems. However, mangrove habitat loss of more than $50 \%$ has been recorded in some parts of the world, and this loss is mostly due to human activities (Romañach et al., 2018). In Indonesia, in 2007 it was reported that mangrove areas had been severely damaged by around $41.9 \%$. The mangrove has 
Table 2 The comparison density of growth stages (mean \pm standard error) in mangroves forest KNP

\begin{tabular}{|c|c|c|c|c|c|c|}
\hline \multirow{2}{*}{ Species } & \multicolumn{2}{|c|}{ Number of trees $\left(\mathrm{ha}^{-1}\right)$} & \multicolumn{2}{|c|}{ Number of saplings $\left(\mathrm{ha}^{-1}\right)$} & \multicolumn{2}{|c|}{ Number of seedlings $\left(\mathrm{ha}^{-1}\right)$} \\
\hline & Mean \& SE & $p$-value & Mean \& SE & $p$-value & Mean \& SE & $p$-value \\
\hline Avicennia alba Blume. & $35.56 \pm 8.89$ & 0.28 & $160.00 \pm 43.55$ & 0.01 & - & - \\
\hline Avicennia lanata (Ridley). & $85.19 \pm 12.39$ & 0.79 & $585.19 \pm 140.74$ & 0.91 & $2,268.52 \pm 438.72$ & 0.27 \\
\hline Avicennia marina (Forssk.) Vierh. & $46.30 \pm 6.03$ & 0.67 & $348.15 \pm 68.29$ & 0.43 & $5,000.00 \pm 954.20$ & 0.97 \\
\hline Bruguiera cylindrical (L.) Bl. & $30.56 \pm 13.13$ & 0.72 & - & - & - & - \\
\hline Bruguiera gymnorrhysa (L.) Lamk. & $287.04 \pm 16.56$ & 0.89 & $762.96 \pm 104.18$ & 0.99 & $5,879.63 \pm 707.89$ & 1.00 \\
\hline Bruguiera sexangula (Lour.) Poir. & $447.78 \pm 29.81$ & 0.91 & $1,585.19 \pm 103.70$ & 1.00 & $11,527.78 \pm 813.81$ & 1.00 \\
\hline Ceriops decandera Griff. Ding Hou. & - & - & - & 0.00 & $1,111.11 \pm 320.75$ & 0.02 \\
\hline Ceriops tagal (Perr.) C.B.Rob. & $248.15 \pm 36.81$ & 0.89 & $1,829.63 \pm 136.47$ & 1.00 & $8,935.19 \pm 1,426.20$ & 1.00 \\
\hline Lumnitzera littorea (Jack) Voigt. & $109.26 \pm 21.16$ & 0.82 & $303.70 \pm 66.34$ & 0.22 & - & - \\
\hline Lumnitzera racemosa Willd. & $38.89 \pm 5.56$ & 0.03 & - & - & - & - \\
\hline Rhizophora apiculata Blume & $457.41 \pm 28.46$ & 0.89 & $1,874.07 \pm 144.43$ & 1.00 & $13,194.44 \pm 675.67$ & 1.00 \\
\hline Rhizophora mucronata Lamk. & $644.44 \pm 38.60$ & 0.91 & $2,140.74 \pm 184.83$ & 1.00 & $14,398.15 \pm 1,662.68$ & 1.00 \\
\hline Rhyzophora stylosa Griff. & $16.67 \pm 5.56$ & 0.02 & $66.67 \pm 22.22$ & 0.00 & - & - \\
\hline Sonneratia Alba J.E. Smith. & $396.30 \pm 36.59$ & 0.90 & $1,296.30 \pm 190.79$ & 1.00 & $9,351.85 \pm 1,337.31$ & 1.00 \\
\hline Sonneratia caseolaris (L.) Engl. & $188.89 \pm 18.37$ & 0.89 & $525.93 \pm 47.89$ & 0.99 & $2,870.37 \pm 309.87$ & 0.82 \\
\hline Xylocarpus granatum Konig. & $44.44 \pm 8.61$ & 0.63 & $555.56 \pm 69.57$ & 0.98 & - & - \\
\hline Total & $8,221.60 \pm 5,171.01$ & 0.96 & $12,088.89 \pm 162.69$ & 1.00 & $77,685.19 \pm 1,298.28$ & 1.00 \\
\hline
\end{tabular}

Table 3 The comparisons of the importance value index (mean \pm standard error) in mangroves forest KNP

\begin{tabular}{|c|c|c|c|c|c|c|}
\hline \multirow{2}{*}{ Species } & \multicolumn{2}{|c|}{ Trees } & \multicolumn{2}{|c|}{ Saplings } & \multicolumn{2}{|c|}{ Seedlings } \\
\hline & Mean \& SE & $p$-value & Mean \& SE & $p$-value & Mean \& SE & $p$-value \\
\hline Avicennia alba Blume. & $16.25 \pm 2.46$ & 0.01 & - & - & - & - \\
\hline Avicennia lanata (Ridley). & - & - & $10.07 \pm 1.90$ & 0.06 & $12.73 \pm 1.73$ & 0.02 \\
\hline Avicennia marina (Forssk.) Vierh. & - & - & $13.07 \pm 2.35$ & 0.01 & $23.65 \pm 4.70$ & 0.88 \\
\hline Bruguiera cylindrical (L.) Bl. & $12.96 \pm 5.41$ & 0.05 & - & - & - & - \\
\hline Bruguiera gymnorrhysa (L.) Lamk. & $36.32 \pm 1.88$ & 1.00 & $11.59 \pm 1.75$ & 0.01 & $13.45 \pm 1.87$ & 0.05 \\
\hline Bruguiera sexangula (Lour.) Poir. & $45.85 \pm 2.39$ & 1.00 & $25.66 \pm 2.45$ & 0.99 & $28.57 \pm 1.75$ & 1.00 \\
\hline Ceriops decandera Griff. Ding Hou. & - & - & - & - & - & - \\
\hline Ceriops tagal (Perr.) C.B.Rob. & $28.93 \pm 3.74$ & 0.81 & $32.55 \pm 2.29$ & 1.00 & $23.62 \pm 2.39$ & 0.98 \\
\hline Lumnitzera littorea (Jack) Voigt. & $14.57 \pm 2.31$ & 0.03 & - & - & - & - \\
\hline Lumnitzera racemosa Willd. & - & - & - & - & - & - \\
\hline Rhizophora apiculata Blume & $39.36 \pm 1.07$ & 1.00 & $33.01 \pm 2.67$ & 1.00 & $30.12 \pm 0.99$ & 1.00 \\
\hline Rhizophora mucronata Lamk. & $50.86 \pm 1.31$ & 1.00 & $33.06 \pm 2.30$ & 1.00 & $33.94 \pm 3.08$ & 1.00 \\
\hline Rhyzophora stylosa Griff. & $13.70 \pm 0.64$ & 0.02 & - & - & - & - \\
\hline Sonneratia Alba J.E. Smith. & $33.43 \pm 2.56$ & 0.99 & $21.12 \pm 2.73$ & 0.88 & $21.73 \pm 2.24$ & 0.95 \\
\hline Sonneratia caseolaris (L.) Engl. & - & - & $12.49 \pm 1.54$ & 0.01 & - & - \\
\hline Xylocarpus granatum Konig. & - & - & $12.22 \pm 1.60$ & 0.01 & - & - \\
\hline
\end{tabular}


been damaged or destroyed by various reasons, especially conversion for other purposes (Kusmana, 2014). It was reported that the KNP mangrove in 2013 had experienced damage of about $1,845.85$ ha or $\pm 26.2 \%$ of the total KNP mangrove area. The damage is due to the conversion of area for other uses (Budiarsa \& Rizal, 2013).

Species that have a low or below average IVI also have a low density, species or number of individuals were small in tree, sapling and seedling categories. Mangrove species with high density do not always have high dominance; one of them was $S$. caseolaris. KNP has the status as a state forest in Indonesia, a Nature Protection Area and must be preserved for its ecosystem sustainability including mangroves. To maintain the sustainability of mangrove forests, attention must be paid to the level of species dominance. For species with low dominance as explained previously, consideration should be given to maintaining and enrichment the species, especially at the three study sites.

Diversity index $\left(\mathbf{H}^{\prime}\right)$ The species diversity index $\left(\mathrm{H}^{\prime}\right)$ for the highest tree category was found in LB mangrove (2.12), for the sapling category also in LB (2.25), for seedlings category was found in PBE (1.99). From three locations with 18 stations, it is known that $\mathrm{H}^{\prime}$ mangrove species in $\mathrm{KNP}$ has an average value of 2.00 or low category. The average value is used as a test in the t-test, with a 95\% confidence level. The significant test results have been known $p$-value for the tree at 0.57 , to sapling 0.54 , and 0.45 for seedlings (Table 4$)$. These results have shown that not all $\mathrm{H}$ 'is below the average value (2.00) or $p$-value $>0.05$ or from six stations of research in three locations there are several $\mathrm{H}^{\prime}>2.00$ (Figure 4).

Each station's diversity index at three locations and three growth rates (trees, saplings and seedlings) at KNP is almost the same as the average range of $1.93 \pm 0.05$ to $2.25 \pm 0.05$. Composition and diversity of mangrove species in the KNP illustrate the characteristics of mangroves in the Borneo region, a tropical area. In tropical ecosystems, climate, and other factors such as soil $\mathrm{pH}$, salinity, nutrients, organic matter, and non-inundation do not usually fluctuate remarkably (Hoque et al., 2015). In the mangrove forest, Sarawak, Malaysia is recorded value for the Shannon-Weiner index (H') of 1.18 (Shah et al., 2016). In Muara Kubu protected areas, West Kalimantan has value for $\mathrm{H}^{\prime}$ of 0.230.87 (Nugroho et al., 2019). Mangroves in Muara Badak has $H^{\prime}$ range of 1.381.53 (Imanuddin \& Simarangkir, 2012).
Mangroves on Sebatik Island, Nunukan, North Kalimantan has $\mathrm{H}^{\prime}$ range of 0.681.25 (Ardiansyah et al., 2012). Mangrove KNP is classified low $\left(\mathrm{H}^{\prime} \geq 23\right)$ but still far greater than the diversity index $\left(\mathrm{H}^{\prime}\right)$ in other Borneo regions.

Evennes index (e) Evenness index (J) of species for each station in three locations and three growth rates is spread evenly. The composition and presence of species were almost the same in the three study locations. The highest evenness index was found in the seedling category in LBE by an average of 0.48 . The lowest index was also found in seedlings in LB with an average of 0.41 . From 18 stations, $\mathrm{J}$ value of mangroves in KNP has an average value of 0.44 or medium category. Significant test results have shown that the $p$-values for the tree of 0.54 , sapling at 0.58 and seedling are 0.43 (Table 4). These results have shown that not all $\mathrm{J}$ is below the average value $(0.44)$ or $p$-value $>0.05$ or from 6 stations at three growth rates in three locations there are several evenness indices of more than 0.44 (Figure 5).

Based on the presence of species that have been recorded at KNP, it is known that the species most often found are $R$. mucronata, $R$. apiculata, B. gymnorrhysa, B. sexangular. Rhizophora sp., and Bruguiera sp. These four species have a high density and IVI compared to other species at all growth stages (tree, sapling and seedling) in the three study sites. The high dominance value of this species was because some of the trees found have a large diameter. Judging from species and structure composition, the mangrove forest in KNP is categorized as old mangrove, or mangrove forests peaked at climax development. Old mangrove community types are often dominated by species of Rhizophora sp. and Bruguiera sp. The tree is big and tall (Kusmana, 2009). In this climax state the balance has been reached, but it is unstable, dynamic and changes that occur are internal, and changes in species composition occur in the mortar. Composition of the species is relatively constant. Mangrove trees composing this community type can reach a diameter of $50 \mathrm{~cm}$. Several undergrowth species grow in mortgages such as Acrostichum aureum (fern) (Ghufrona et al., 2015). KNP mangrove forests have anthropogenic impacts, but the impacts are not too large, and therefore mangroves are not disturbed and are still natural. Vegetative indicators such as composition, density, important value index, and species diversity were evidence that the KNP mangrove forest is well protected.

Table 4 The comparison $\mathrm{H}^{\prime}$ and J of growth stages (mean \pm standard error) in mangroves forest KNP

\begin{tabular}{lcccr}
\hline \multirow{2}{*}{ Class of growth } & \multicolumn{4}{c}{ Diversity index $\left(\mathrm{H}^{\prime}\right)$} \\
\cline { 2 - 5 } & LB & KB & PBE & $p$-value \\
\hline Trees class & $2.12 \pm 0.06$ & $1.98 \pm 0.06$ & $1.93 \pm 0.05$ & 0.57 \\
Saplings class & $2.25 \pm 0.05$ & $2.01 \pm 0.05$ & $2.01 \pm 0.05$ & 0.54 \\
Seedlings class & $1.97 \pm 0.06$ & $2.03 \pm 0.06$ & $1.99 \pm 0.05$ & 0.45 \\
\hline \multicolumn{4}{c}{ Evennes index $(\mathrm{J})$} \\
\cline { 2 - 5 } & LB & KB & PBE & $p$-value \\
\hline Trees class & $2.12 \pm 0.06$ & $1.98 \pm 0.06$ & $1.93 \pm 0.05$ & 0.54 \\
Saplings class & $2.25 \pm 0.05$ & $2.25 \pm 0.05$ & $2.01 \pm 0.05$ & 0.58 \\
Seedlings class & $1.97 \pm 0.06$ & $1.97 \pm 0.06$ & $2.03 \pm 0.05$ & 0.43 \\
\hline
\end{tabular}




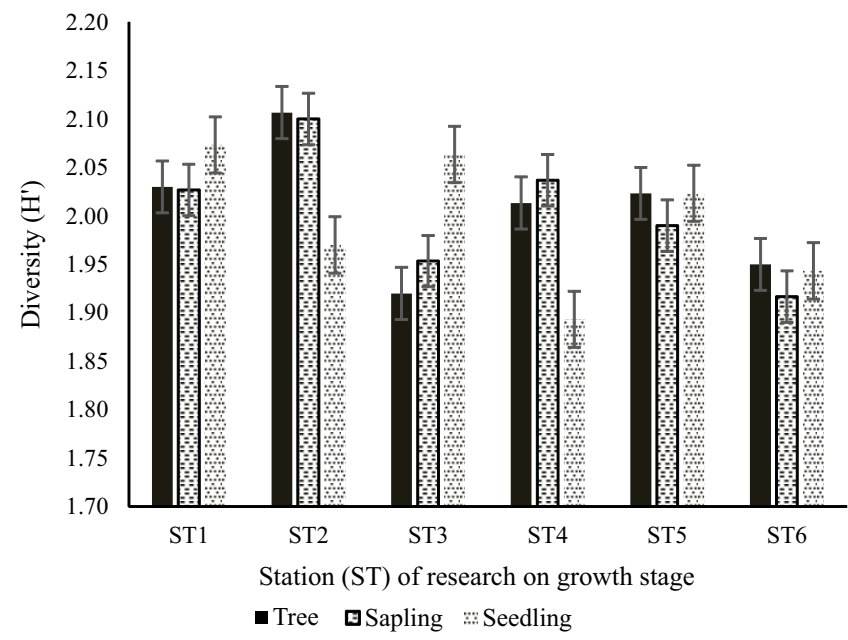

Figure 4 The comparisons average of diversity index $\left(\mathrm{H}^{\prime}\right)$ on six station in mangrove forest KNP.

\section{Conclusion}

KNP had a valuable and preserved forest in the East Kalimantan Province. It is declared as a nature conservation area in Indonesia. The results of this study indicated that the mangrove forest stands were healthy and well maintained. Previous research stated that there were 12 species of KNP mangroves, then in this study, 21 species were found. Twenty-one of these species consists of 16 species of trees, two species of ferns, one species of pandan, one species of parasite, and one palm species. Species of family Rhizophoraceae are often found and have dominated the mangrove forests in KNP. $R$. mucronata was a species that has been dominated the growth stages of tree, sapling, and seedling. The diversity of vegetation that develops can be a potential biodiversity site, and the location has the potential for ecotourism, education, and research. This study's findings could be used as the primary source of information and provide necessary data to assess mangrove ecosystems' environmental parameters in the region. Furthermore, detailed research on the forest's mangrove ecology and biodiversity aspects is needed for a sustainable mangrove management policy.

\section{Acknowledgment}

This study has been completed with the good cooperation of the East Kutai College of Agriculture (STIPER Kutai Timur) and team of Lecturers from the Faculty of Forestry, Gadjah Mada University. Sincere thanks to the Kutai National Park Service for permission so that research activities in the mangrove forest can run smoothly.

\section{References}

Ardiansyah, W. I., Pribadi, R., \& Soenardjo, N.. (2012). Struktur dan komposisi vegetasi mangrove di kawasan pesisir Pulau Sebatik, Kabupaten Nunukan, Kalimantan Timur. Journal of Marine Research, 1(2), 203-215. https://doi.org/10.14710/jmr.v1i2.2039

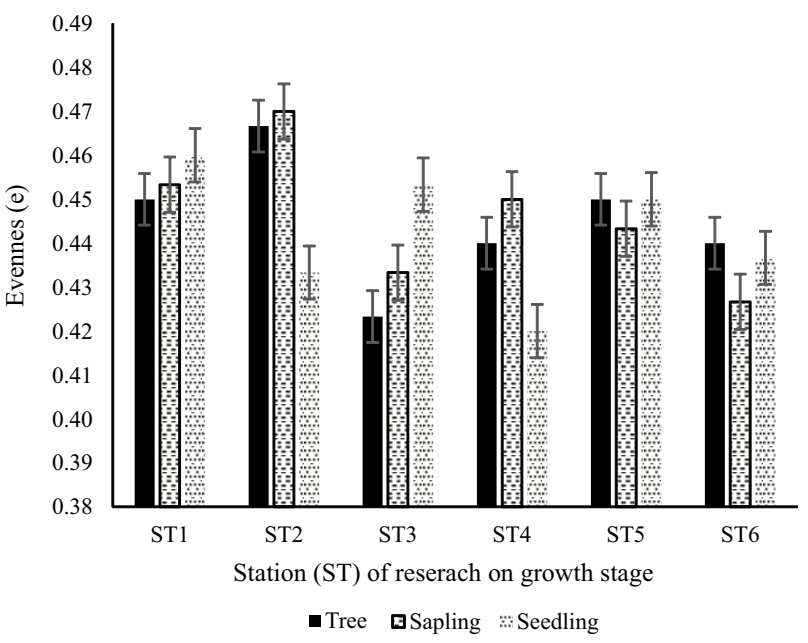

Figure 5 The comparisons average of evennes index (J) on six station in mangrove forest KNP.

Barbour, M. G. B., Michael, G., \& Burk, J. H. (1987). Terrestrial plant ecology. California: Benyamin Cumming.

Brander, L. M., Wagtendonk, A. J., Hussain, S. S., McVittie, A., Verburg, P. H., de Groot, R. S., \& van der Ploeg, S. (2012). Ecosystem service values for mangroves in Southeast Asia: A meta-analysis and value transfer application. Ecosystem Services, 1(1), 62-69. https://doi.org/10.1016/j.ecoser.2012.06.003

Budiarsa, A., \& Rizal, S. (2013). Pemetaan dan analisis tingkat kerusakan hutan mangrove di Taman Nasional Kutai berdasarkan data citra setelit Landsat ETM dan kerapatan vegetasi. Jurnal Ilmu Perikanan Tropis, 19(1), 54-61.

Curtis, J. T., \& Mcintosh, R. P. (1950). The interrelations of certain analytic and synthetic phytosociological characters. Ecology, 31(3), 434-455. https://doi.org/ $10.2307 / 1931497$

Djufri, Wardiah, \& Muchlisin, R. (2016). Plants diversity of the deforested peat-swamp forest of Tripa, Indonesia. Biodiversitas Journal of Biological Diversity, 17(1). https://doi.org/10.13057/biodiv/d170150

Eddy, S., Ridho, M., Iskandar, I., \& Mulyana, A. (2019). Species composition and structure of degraded mangrove vegetation in the Air Telang Protected Forest, South Sumatra, Indonesia. Biodiversitas Journal of Biological Diversity, 20(8), 2119-2127. https://doi.org/10.13057/ biodiv/d200804

English, S., Wilkinson, C., \& Baker, V. (1997). Survey manual for tropical marine resources. Townsville: Australian Institute of Marine Science.

Fawzi, N. I., \& Husna, V. N. (2017, Januari 2628). 
Evaluation of mangrove forest change and fragmentation in Mahakam Delta, East Kalimantan for coastal management [Paper presentation]. 2nd International Forum on Sustainable Future in Asia (2nd NIES International Forum), Bali, Indonesia.

Ghufrona, R., Kusmana, C., \& Rusdiana, O. (2015). Komposisi jenis dan struktur hutan mangrove di Pulau Sebuku, Kalimantan Selatan. Jurnal Silvikultur Tropika, 6(1), 15-26.

Giesen, W., Wulffraat, S., Zieren, M., \& Scholten, L. (2007). Mangrove guidebook for Southeast Asia. Bangkok: FAO Regional Office for Asia and the Pacific.

Herison, A., Yulianda, F., Kusmana, C., Nurjaya, I. W., \& Adrianto, L. J. (2014). The existing condition of mangrove region of Avicenia marina, Its: distribution and functional transformation. Jurnal Manajemen Hutan Tropika, 20(1), 26-36. https://doi.org/10.7226/jtfm. 20.1.26.

Hoque, M. M., Kamal, A. H. M., Idris, M. H., Ahmed, O. H., Hoque, A. T. M. R., \& Billah, M. M. (2015). Litterfall production in a tropical mangrove of Sarawak, Malaysia. Zoology and Ecology, 25(2), 157-165. https://doi.org/ $10.1080 / 21658005.2015 .1016758$

Imanuddin, \& Simarangkir, B. (2012). Analisis vegetasi kawasan hutan mangrove di Teluk Pangempang Kecamatan Muara Badak Kabupaten Kutai Kertanegara. Jurnal Kehutanan Tropika Humida, 5(1), 15-24.

Kartika, K. F., Istomo, I., \& Amanah, S. (2018). Mangrove diversity in production forest management unit (FMU) Bulungan Unit VIII North Kalimantan. Media Konservasi, 23(3), 253-261. https://doi.org/10.29244/ medkon.23.3.253-261

Kathiresan, K., \& Bingham, B. (2001). Biology of mangroves and mangrove ecosystems. Advances in Marine Biology, 40, 81-251 https://doi.org/10.1016/ S0065-2881(01)40003-4

[KNP] Kutai National Park. (2015). Data dasar Taman Nasional Kutai. Bontang: Balai Taman Nasional Kutai.

Kusmana, C. (2009, August 18). Pengelolaan sistem mangrove secara terpadu [Paper presentation]. Workshop Pengelolaan Ekosistem Mangrove di Jawa Barat, Jatinangor, Jawa Barat, Indonesia.

Kusmana, C. (2014). Distribution and current status of mangrove forests in Indonesia. In I. Faridah-Hanum, A. Latiff, K. R. Hakeem, \& M. Ozturk (Eds.), Mangrove ecosystems of Asia: Status, Challenges and Management Strategies (pp. 37-60). New York: Springer. https://doi.org/10.1007/978-1-4614-8582-7_3

Kusmana, C., \& Sukristijiono. (2016). Mangrove resource uses by local community in Indonesia. Jurnal Pengelolaan Sumberdaya Alam dan Lingkungan, 6(2),

\section{7-224. https://doi.org/10.29244/jpsl.6.2.217}

Magurran, A. E. (1988). Ecological diversity and its measurement. Victoria: Princeton University Press. https://doi.org/10.1007/978-94-015-7358-0

Noor, Y. R., Khazali, M., \& Suryadiputra, I. N. N. (1999). Panduan pengenalan mangrove di Indonesia. Bogor, Indonesia: PKA/WI-IP (Wetlands InternationalIndonesia Programme).

Nugroho, T. S., Fahrudin, A., Yulianda, F., \& Bengen, D. G. (2019). Structure and composition of riverine and fringe mangroves at Muara Kubu protected areas, West Kalimantan, Indonesia. Aquaculture, Aquarium, Conservation \& Legislation, 12(1), 378-393. Retrieved from http://www.bioflux.com.ro/docs/2019.378393.pdf.

Nurhidayah, Maidie, A., \& Gunawan, B. I. (2009). Analisis tegakan hutan mangrove Kota Bontang. Jurnal Kehutanan Tropika Humida, 2(2), 192-203.

Pielou, E. C. (1975). Ecological diversity. New York: Wiley Interscience.

Romañach, S. S., DeAngelis, D. L., Koh, H. L., Li, Y., Teh, S. Y., Barizan, R. S. R., \& Zhai, L. (2018). Conservation and restoration of mangroves: Global status, perspectives, and prognosis. Ocean \& Coastal Management, 154, 72-82. https://doi.org/10.1016/ j.ocecoaman.2018.01.009

Saenger, P. (1999). Sustainable management of mangroves. In J. Rais, L. Pantimena, R. Dahuri, J. Plouffe (Eds.), Integrated coastal and marine resource management: Proceedings of international symposium, Malang, Indonesia

Sayektiningsih, T., \& Gunawan, W. (2012). Kondisi sosial ekonomi masyarakat di sekitar hutan mangrove Taman Nasional Kutai, Kalimantan Timur. In Pratiwi, I W. S. Dharmawan, M. Turjaman, H. Gunawan, \& Kuntadi (Eds.), Prosiding seminar hasil-hasil penelitian: Mengelola konservasi berbasis kearifan lokal (pp. 89100). Balikpapan: Balai Penelitian Teknologi Konservasi Sumber Daya Alam.

Shah, K., Kamal, A. H. M., Rosli, Z., Hakeem, K. R., \& Hoque, M. M. (2016). Composition and diversity of plants in Sibuti mangrove forest, Sarawak, Malaysia. Forest Science and Technology, 12(2), 70-76. https://doi.org/10.1080/21580103.2015.1057619

Suk-ueng, N., Buranapratheprat, A., Gunbua, V., \& Leadprathom, N. (2013). Mangrove composition and structure at the Welu Estuary, Khlung District, Chanthaburi Province, Thailand. IOSR Journal of Environmental Science, Toxicology and Food Technology, 7(5), 17-24. https://doi.org/10.9790/24020751724 
Thomas, N., Lucas, R., Bunting, P., Hardy, A., Rosenqvist, A., \& Simard, M. (2017). Distribution and drivers of global mangrove forest change, 1996-2010. PLOS ONE, 12(6), e0179302. https://doi.org/10.1371/ journal.pone. 0179302

Warsidi, \& Endayani, S. (2017). Komposisi vegetasi mangrove di Teluk Balikpapan Provinsi Kalimantan
Timur. AGRIFOR: Jurnal Ilmu Pertanian dan Kehutanan, 16(1), 115-124.

Wijaya, N. I. (2011). Pengelolaan zona pemanfaatan ekosistem mangrove melalui optimasi pemanfaatan sumberdaya kepiting bakau (Scylla serrata) di Taman Nasional Kutai Provinsi Kalimantan Timur (dissertation). Bogor: IPB University. 